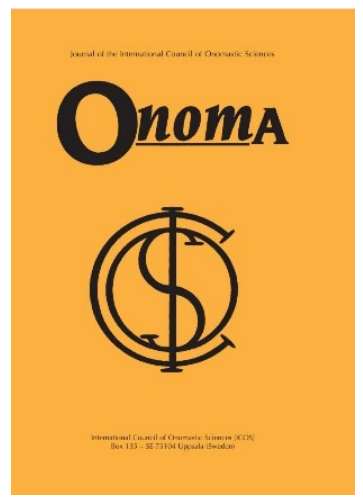

Onoma 54

Journal of the International Council of Onomastic Sciences

ISSN: 0078-463X; e-ISSN: 1783-1644

Journal homepage: https://onomajournal.org/

\title{
Individual names of the upper classes of Chieri (Turin) in the 16th century
}

DOI: 10.34158/ONOMA.54/2019/9

\author{
Elisabetta Rossi \\ University of Turin \\ Corso Matteotti 0 \\ 10121 Torino \\ Italy \\ elisabetta.rossi@unito.it
}

To cite this article: Rossi, Elisabetta. 2019. Individual names of the upper classes of Chieri (Turin) in the 16th century. Onoma 54, 161-179. DOI: 10.34158/ONOMA.54/2019/9

To link to this article: https://doi.org/10.34158/ONOMA.54/2019/9

\section{(C) Onoma and the author.}

\section{Individual names of the upper classes of Chieri (Turin) in the 16th century}

Abstract: This contribution, based on the data which I collected for my doctoral dissertation, aims to reconstruct the changes that marked onomastic preferences among the ruling classes in the town of Chieri (Turin, Piedmont) in the aftermath of the Council of Trent (1545-1563). Chieri is a settlement with a thousandyear history and the research is based on the findings made on the 16th century baptismal registers of the local cathedral (1567-1581). In order to process data, a digital archive was created in a relational database in Microsoft Access, with multimodal data processing. Thanks to the processing of data relating to the names of the fathers (titles with which they are registered and family names) it was possible to reconstruct how many and which of the baptized belong to families of the city's élite. The social situation is particularly significant because of the many historical events 
that affected the high classes of Chieri in those times: several foreign dominations (Spanish and French), religious persecution, inequitable taxation and finally co-option in the court of Turin by the Duke Emmanuel Philibert, after the Savoy restoration. This report also reveals the various elements of onomastic fashion and how they reflect the historical and social forces of the era. Among these, the tendency of naming after the saints, the rediscovery of classics and the love for contemporary literature. The differences between the onomastics of the whole system and the naming preference of the ruling classes will also be explored.

Keywords: Anthroponymy, stratigraphy, aristocracy, 16th century, Piedmont, Turin, Savoy.

\section{Prénoms des classes aisées de Chieri (Turin) au XVIe siècle}

Résumé : Cet article, basée sur les données que j'ai recueillies pour ma thèse de doctorat, vise à reconstruire les changements qui ont marqué les préférences onomastiques parmi les classes dirigeantes de la ville de Chieri (Turin, Piémont) au lendemain du Concile de Trente (1545-1563). Chieri est une ville avec une histoire millénaire et mon projet se déroule autour des découvertes faites sur les registres baptismaux du XVIe siècle de la cathédrale locale (1567-1581). Afin de traiter les données, une archive numérique a été créée d'après des données relationnelle, dans Microsoft Access. Grâce au traitement des données relatives aux noms des pères (titres avec lesquels ils sont enregistrés et noms de famille), il a été possible reconstruire combien de baptisés appartiennent aux familles de l'élite de la ville. La situation sociale est particulièrement intéressante à cause des nombreux événements historiques qui ont affecté les classes supérieures de Chieri à cette époque : plusieurs dominations étrangères (espagnoles et françaises), persécutions religieuses, imposition injuste et enfin cooptation à la cour de Turin par le duc Emmanuel Philibert, après la restauration de la Maison de Savoie. Ce rapport révèle également les différents éléments de la mode onomastique et comment ils reflètent les forces historiques et sociales de l'époque. Parmi ceux-ci, la tendance à donner aux enfants les noms des saints, la redécouverte des classiques et l'amour pour la littérature contemporaine. Seront également explores les différences entre les préférences onomastiques de la classe dirigeante et l'onomastique de l'ensemble du système.

Mots-clés : Prénoms, anthroponymie, stratigraphie, aristocratie, XVIe siècle, Piémont, Turin, Savoie.

\section{Vornamen des Führungsschichtes von Chieri (Turin) in dem XVI Jahrhundert \\ Zusammenfassung: Dieser Beitrag stützt sich auf die Daten, die ich für meine Doktorarbeit sammelte, und versucht die Veränderungen der onomatologischen Vorzüge der Führungsschichten nach dem Tridentinischen Konzil (1545-1563) in der Stadt von Chieri (Turin, Piemonte) zu rekonstruieren. Chieri ist eine Siedlung mit einer tausendjährigen Geschichte und die Forschung stützt sich auf die Ermittlung der Taufregister des Domes, die auf das XVI Jahrhundert zurückgehen (1567-1581). Um die Daten zu verarbeiten, wurde ein digitales Archiv als eine relationale Datenbank in Microsoft Access erschaffen, mit multimodalen Datenverarbeitung. Die Verarbeitung der Daten, die mit den väterlichen Namen verbunden sind (Titel und Familiennamen), erlaubte $\mathrm{zu}$ rekonstruieren, wie viele und welche der Getaufte zur Familien der städtlichen Elite gehörten. Die soziale Lage ist relevant wegen der vielen historischen}


Zusammenhänge, die in dieser Epoche die Führungsschichten von Chieri interessierten: mehrere Fremdherrschaften (Spanische, Französische), religiöse Verfolgung, ungerechte Besteuerung und Kooptierung durch Emanuele Filiberto von Savoia in den Einflussbereich des turinischen Hofes. Dieser Beitrag forscht auch die verschiedenen Elemente der namenkundlichen Mode und die Art und Weise, wie sie die sozialen und geschichtlichen Mächte der Epoche widerspiegeln: darunter, die Namengebung nach den Heiligen, die Wiederentdeckung der Klassik und die Liebe zur Literatur dieser Zeit. Man wird auch die Differenzen zwischen der Onomastik des gesamten Systems und den Vorzügen der Führungsschichten ermitteln.

Schlüsselbegriffe: Anthroponimie, Stratigraphie, Aristokratie, XVI Jahrhundert, Piemonte. 


\title{
Individual names of the upper classes of Chieri (Turin) in the 16th century
}

\author{
ELISABETTA ROSSI
}

\begin{abstract}
Anthroponymy, with its particular vocation to the reconstruction of the plots between the individuals and of their connection with the community where they act, allows to get to know places of our history that are still obscure to us, giving them back to us in all the complexity that is hidden under the name weaving.

As Wilson (1998: XII) states, "names are connotative, but in a way that requires social and historical analysis to explain". Names identify individuals and are often the focus of a person's sense of identity. In Bloch's (1964: I, VII) words, the name also "defines an individual's position in his family and within society at large; it defines one's social personality". In other words, it classifies a person.
\end{abstract}

\section{Documentary sources for anthroponymy between the Middle Ages and Early Modern Age}

To increase knowledge in the anthroponymic field, scholars can rely on different types of documentary sources. The general historical sources that can be used for the purposes of onomastic research are essentially referable to three types: political-juridical documents (i.e. oaths of loyalty, peace pacts, agreements entered into between two or more communities), tax or administrative documents (land registers, appraisals, deliveries, censuses), or documents of ecclesiastical nature (baptismal, matrimonial and obituary registers). The baptismal registers, in a particular way, are both a potentially very rich source of material (even if a late source) and a reliable source that has the merit of guaranteeing the certain origin of a name from the investigated territory, if referred to extended and cohesive communities (Papa 2005: 11).

The 16th century is particularly interesting to study: this period has been investigated in its changes between the rediscovery of classical culture, typical of the Renaissance, and the entry into force of the norms of the Council of Trent (1545-1563). Furthermore, the counter-reformation pushed the pressure on the use of the names of saints (Sestito 2014: 205). The practice of registering the name and the obligation to draw up the registers is a rule that came into force following the provisions issued by the Council. Three years after the end of the Council of Trent, in 1566, Pope Pius V wrote the Catechismo del Concilio di Trento ad uso dei parroci (original title: Catechismus ex decreto 
Concilii Tridentini, ad parochos, Pii Quinti Pont. Max. iussu editus) $)^{1}$. The second part of the treatise is dedicated to sacraments and, in particular, to the baptism. Regarding the imposition of the name, in paragraph LXXIII it is written:

[...] finally, a name is given to the baptized. It shall be chosen from those who, due to their distinguished virtue and profound religiosity, is to be on the list of saints. Thus the similarity of the name will easily incite the emulation of virtue and holiness; by practicing the imitation of the saint whose name he bears, the believer will pray him, hoping to have him as guardian of his own health of body and spirit. Therefore, those who look for pagan names, or rather worse, for characters who were among the most wicked, are worthy of blame. How much respect these people show of Christian piety, being so much pleased of the memory of wicked individuals and working to such an extent that profane names echo from all over. (Translated from the Latin text of Catechismus ex decreto Concilii Tridentini, ad parochos 1567, Pars II. Quaestio LXXIII).

The settlement chosen for this contribution is the town of Chieri, near Turin in Piedmont, in the north-west of Italy.

\section{Chieri. A short history of the millenary town}

The town of Chieri is located in the region of Piedmont, in the northwest of Italy, in a crucial transit area between Asti and Turin. The municipality nowadays counts just over 36,000 inhabitants.

According to historians such as Cibrario (1827), Gabotto (1913-1924) and Alessio (1905), Chieri used to be a Roman municipality (Bassignana 1986: 13). Before the intervention of Rome, which do archaeologists date at the end of the 2 nd century $\mathrm{BC}$, it was a pre-Roman, Ligurian centre. At the origins of the toponym, there is the gallic root *karr(o), attested in the Celtic area both as common name and as proper name (DTI 1997, see the toponomastic sheet Chieri).

Archaeological findings allow us to infer that the Christian community of Chieri in the 5th century was already well structured and that a church and baptistery were located there. Subsequently, the church was rebuilt between 1010 and 1037 (Bassignana 1986: 15), as stated by the testament of Bishop Landolfo of Turin, cited by Bosio (1878: 20). It was named Collegiate, as the munificent Bishop rebuilt it and entrusted it to a "college" of priests. The construction of the Gothic church, as we know it today, began on 6 February 1406 (Valimberti 1928: 59).

1 For more information on the topic, see Giugni (2004: 81). 


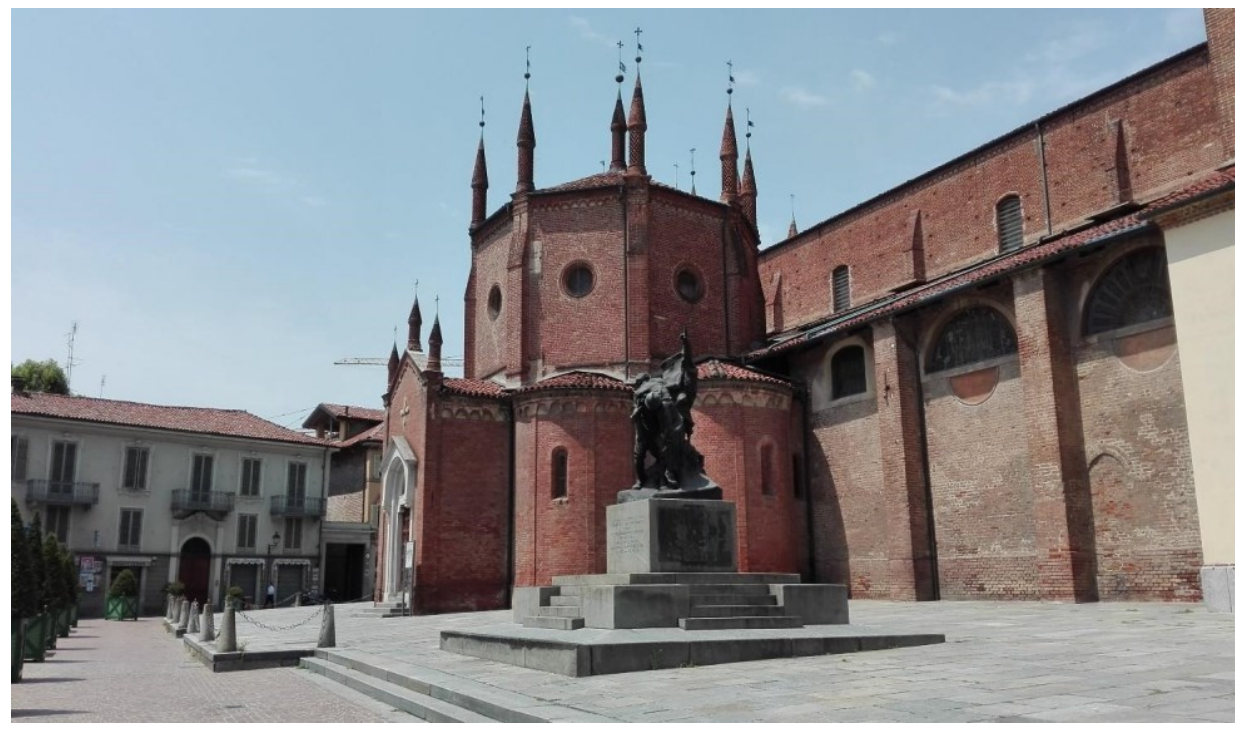

Figure 1: The Collegiata of Santa Maria della Scala of Chieri as it is today

Some eminent scholars (Allegra 1987 in particular) identified Chieri as a centre that is interesting to investigate in its passage from the Middle Ages to the Modern Age, the protagonist of a unique parable of its kind. In the 16th century, Chieri was in fact the theatre of historical events of considerable importance, which necessarily left a mark on the demographic, economic and social development of the community. The natural disasters, two floods and two plagues, that struck the town in the first 20 years of the century, are registered in the chronicle of the contemporary notary, Bartolomeo Martinetti (Cibrario 1827: 353). Later, the loyalty of Chieri to the House of Savoy, sanctioned by an ancient pact of dedication of 1347 (Allegra 1987: 20), involved the locals (whose name is Chieresi) in a long war alongside the dukes.

Conquered and harshly sacked by the imperial troops of Charles $\mathrm{V}$ in 1537 (Cibrario 1827: 356), in 1551 the city passed under the control of the French army, which was much more benevolent and appreciated by the population. During this period, Calvinist theories penetrated massively and made Chieri one of the cities with the highest concentration of Protestants in northern Italy. The peace of Câteau-Cambrésis in 1559 allowed Chieri to return under the Savoy, although the city was one of the five strongholds that Henry II of France wanted to maintain until the end of the disputes with the duke Emanuele Filiberto, and whose possession was not actually abandoned until 1562. The Chieresi, economically favoured by the previous French domination, coldly welcomed the Savoy restoration (Allegra 1987: 164). They were afraid that the change of government could harm their interests. In fact, starting from 1562, the city lived a political, social and demographic decline, due to the corrosive initiatives of the Savoy court. 


\section{Data. The baptismal registers}

The oldest baptismal registers of the parish of Santa Maria della Scala, preserved in the archive, extend from 1567 to 1604. The first two registers also contain records of marriages, which are recorded on separate volumes starting from 1577. The complete series consisted of eight registers, but the sixth (which covered the period from 1597 to 1599) has been stolen. The registers have different dimensions and spellings and are mostly written in Latin (Figure 2 ), but a smaller percentage of documents are written in vernacular Italian (Figure 3 ) in the years 1576-1577 and 1600.

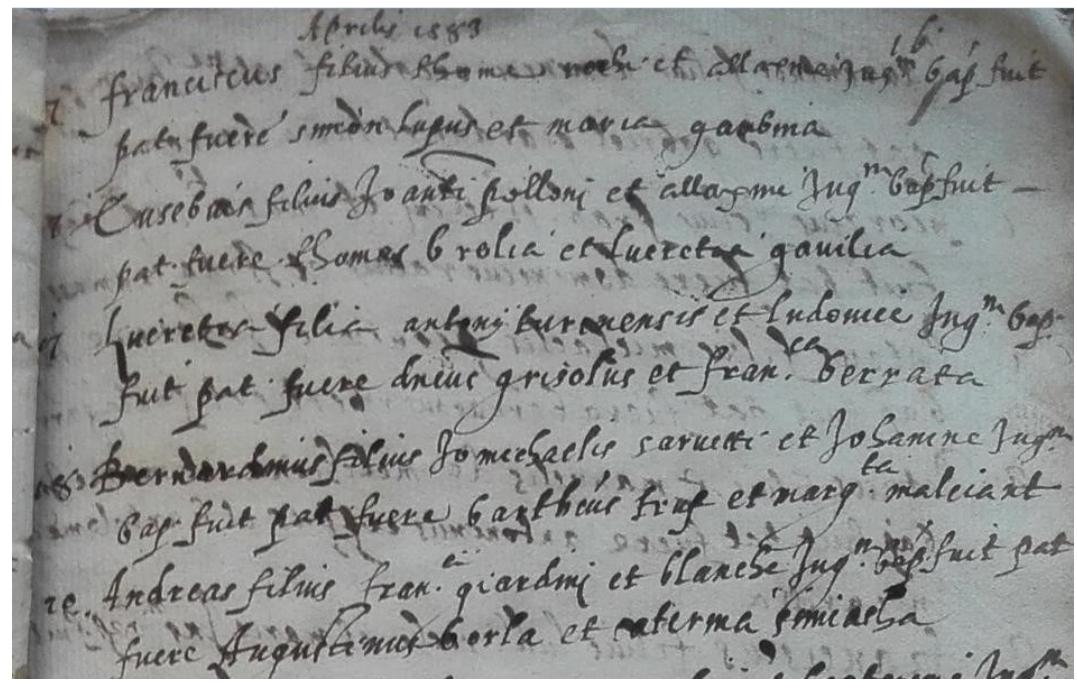

Figure 2: Baptismal register in Latin, 1589

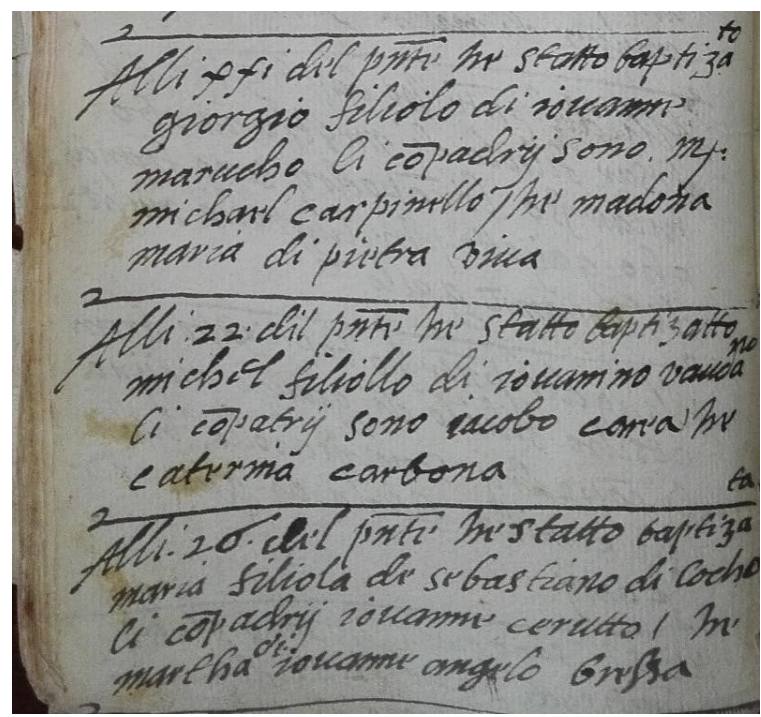

Figure 3: Baptismal register in Italian, 1576 
In order to conduct the studies that are the core of my doctoral dissertation (Rossi 2019), I decided to transcribe the names contained in the registers for 15 consecutive years (from 1567 to 1581) and then the names of the years 1589-1600, with the aim of analysing the onomastic changes in diachrony. The onomastic data transcribed and taken in consideration for the study were:

- the date when the baptism took place;

- the first name of the baptized child;

- the names of the father;

- the names of the mother;

- the names of the godfather (or godfathers, since in certain circumstances there are more than one);

- the names of the godmother (also in this case there are, sometimes, more than one);

- the name of the priest who officiated the ritual.

In order to process the data, I have created a digital archive in a relational database in Microsoft Access (Figure 4), with multimodal data processing, ready for future exportation on other platforms. Thanks to the processing of data relating to the fathers' names (titles which they are registered with ${ }^{2}$ and family names), it is possible to reconstruct how many baptized babies belonged to the aristocratic families of Chieri and who they were. Here, it would be interesting to compare the onomastic choices made by the aristocrats with those emerging from the system. It is also possible to reconstruct some of the events that have affected the ruling classes of Chieri during that turbulent historical period.

As Allegra (1987: 165-171) has pointed out, the number of families of notable decreased in Chieri at the end of the 16th century. This can be associated with factors related to the restoration and the interference of the House of Savoy: the persecutions of the Protestants from the Duke Emanuele Filiberto, the imposition of unfair taxes on commercial activities and the coopting of nobles at court. All of these factors are evident in the chart in Figure 5 , which reconstructs the numbers of élite and non-élite families based on baptismal records, (those whose parents are registered with titles) present in four of the studied years and the total number of recorded acts. These data are useful for a diachronic comparison. Despite the presence of a gradual increase in births, there is a progressive and evident decline in the presence of the aristocracy, which goes from representing $11.6 \%$ of families in 1569 to $8 \%$ in 1600 .

2 The titles (all in the genitive case) are: domini, egregii, illustris, magnifici domini, nobilis and signor in sources written in vernacular Italian. Some writers prefer some titles in place of others and it may therefore happen to find the same person indicated with a different title in different years. 


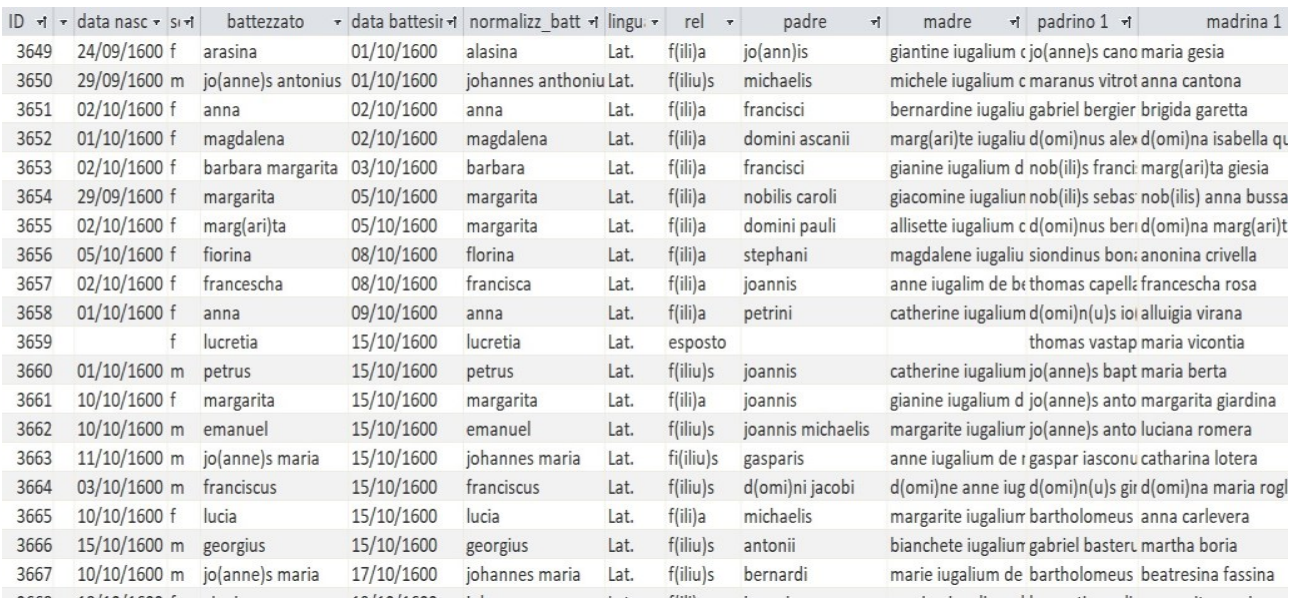

Figure 4: An example from the onomastic database

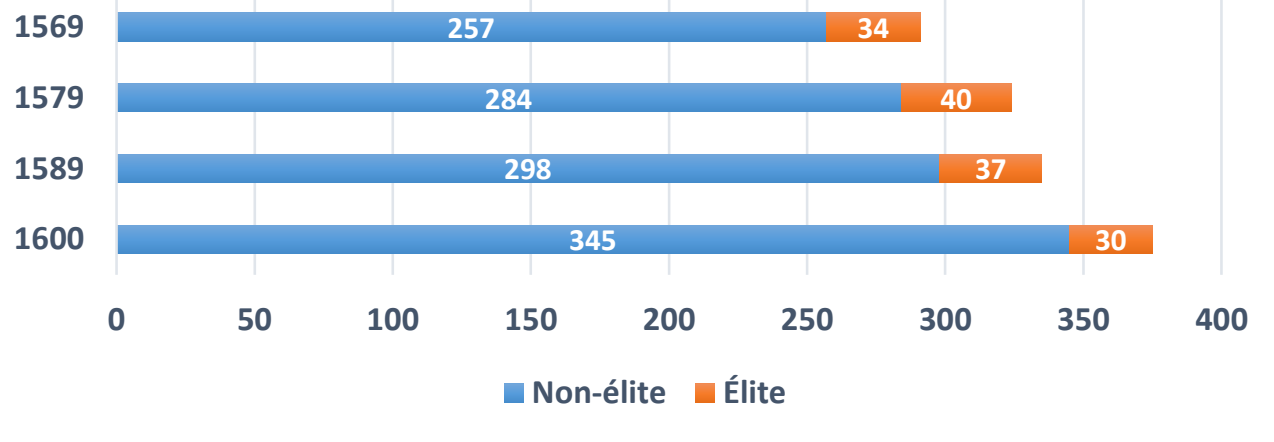

Figure 5: Aristocrats in baptismal acts in 1569-1600

\section{Baptismal names: The ruling classes' choices}

In order to have the richest name stock for this investigation, I have selected the data from the longest continuous period in the database, from 1567 to 1581. During that fifteen-year period, there were altogether 3,041 baptismal acts, of which $306(10.6 \%)$ were aristocrats. Of these aristocrat children, 152 were boys and 154 girls.

Table 1 presents the feminine names chosen by aristocratic families from 1567 to 1581 in order of frequency. There are 59 nominal types (different names) for 154 children. The chart in Figure 6 shows have those names are distributed in the categories of religious, historical, classical, literary and other names. It is important to notice that the borders between these categories are not completely distinct, because every name could be included in many categories. The purpose of the categorization is to enlighten the spirit of how that name was perceived in that time and in that place. 
Table 1: Feminine names chosen by aristocratic families from 1567 to 1581

\begin{tabular}{|c|l|c|c|}
\hline Rank & Name & Units & \% of 154 \\
\hline 1 & Lucretia & 12 & 7.8 \\
\hline 2 & Anna, Catharina & 11 & 7.2 \\
\hline 4 & Johanna & 10 & 6.5 \\
\hline 5 & Margarita & 8 & 5.2 \\
\hline 6 & Maria & 7 & 4.5 \\
\hline 7 & Delia, Francisca, Julia, Laura, Lucia & 5 & 3.2 \\
\hline 12 & Angela, Leonora, Ludovica & 4 & 2.6 \\
\hline 15 & Adriana, Isabel & 3 & 1.9 \\
\hline 17 & $\begin{array}{l}\text { Aliseta, Anna Maria, Antonia, Aurelia, Bartholomea, } \\
\text { Camilla, Hieronima, Magdalena, Paula }\end{array}$ & 2 & 1.3 \\
\hline 26 & $\begin{array}{l}\text { Angelica, Avaseta, Barbara, Basilica, Beatrixina, } \\
\text { Bernardina, Blanca, Bona, Centuria, Clauda, Dominica, } \\
\text { Dorelix, Erminea, Florina, Francheta, Fulvia, Gaspara, } \\
\text { Genevra, Hortensia, Jacoma, Lavinea, Livia, Luciana, } \\
\text { Marta, Octavia, Olimpia, Prudentia, Ruffina, Teresina, } \\
\text { Uriana, Valenza, Victoria, Violans, Virginea }\end{array}$ & 1 & 0.6 \\
\hline
\end{tabular}

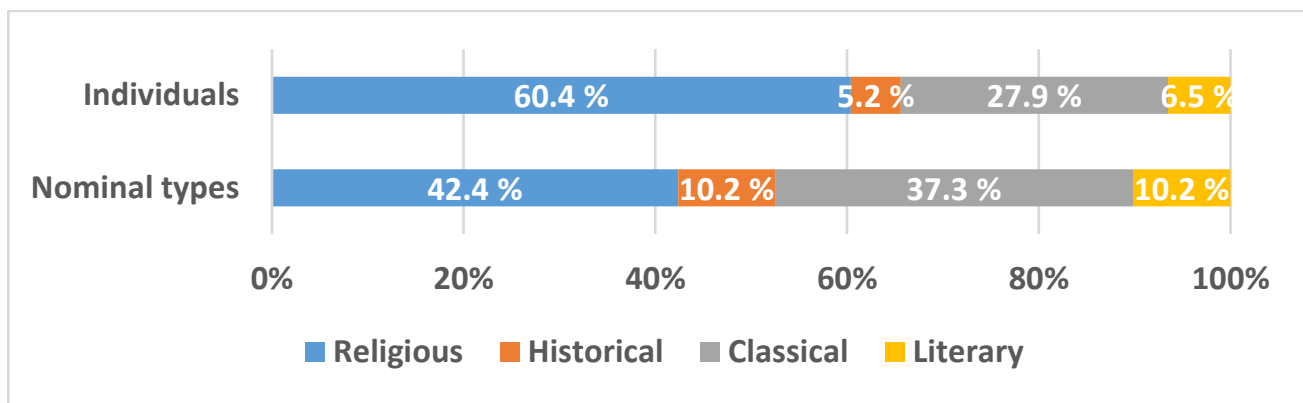

Figure 6: Individual and nominal types of aristocrat female names in 1567-1581 sorted by category

Most aristocrats have chosen a religious name for a female child: those make $42 \%$ of all nominal types and $60 \%$ of all individuals. The majority of names in the category are saints' names: Catharina, Anna, Johanna, Margarita, Francisca, Lucia, Ludovica, Aliseta, Antonia, Bartholomea, Hieronima, Magdalena, Paula, Avaseta (variant of Evasia), Barbara, Basilica, Bernardina, Jacoma, Marta and Teresina. There are, however, also a few devotional names ${ }^{3}$ : Maria, Anna Maria, Angela, Dominica and Gaspara. The choice of these religious names benefits above all those names that hold also a historicaldynastical component. Among these are the widespread Catharina and Margarita, which are linked to the custom of the House of Savoy in Piedmont. ${ }^{4}$

3 Devotional names are a subcategory of religious names referring to religious figures not completely assimilable to the set of saints. See the introduction to NPI (2005) for further information.

4 There is a large number of duchesses of all times from the House of Savoy called Margarita and Catarina (NPI 2005 s.v. Caterina, Margherita). 
As it will be observed further on, many other names are affected by the success of the corresponding male name.

The percentage of classical names is very significant as well. They make $28 \%$ of all individuals and $37 \%$ of all nominal types, including Lucretia, the most common female aristocrat name during the research period. Those names are drawn from the classics: Lucretia, Julia, Delia, Aurelia, Camilla, Adriana, Centuria, Clauda (variant of Claudia), Erminia, Florina, Fulvia, Lavinea, Livia, Luciana, Octavia, Olimpia, Prudentia, Ruffina, Valenza, Victoria and Virginia. These choices demonstrate that the rediscovery of the classics, typical of the Renaissance, is a prerogative of the upper classes. The choices show, an alternation of models of Latin virtue ( Lucretia $^{5}$, Camilla ${ }^{6}$, Virginea ${ }^{7}$ ), references to the "auguste", wives and daughters of generals and emperors $\left(\right.$ Julia $^{8}$ and Livia $\left.{ }^{9}\right)$, and figures of classical antiquity revived by 16 th century works $\left(\right.$ Fulvia $^{10}$, Hortensia $^{11}$, Delia $^{12}$, Lavinea $\left.^{13}\right)$. Moreover, there are extensions of masculine classical names such as Adriana, Clauda and Luciana, descriptive names like Ruffina ${ }^{14}$ and Florina ${ }^{15}$, and abstract names like

5 Lucretia, in the Roman founding myth, was a noblewoman in ancient Rome. Her rape by the Etruscan king's son Sextus Tarquinius was the cause of a rebellion that overthrew the Roman monarchy and led to the transition of Roman government from a kingdom to a republic (NPI 2005 s.v. Lucrezia).

6 Camilla of the Volsci, according to the Roman tradition, was the daughter of King Metabus and Casmilla, servant of goddess Diana and warrior virgin, associated to the Amazons as well (Paschalis 1997: 378).

7 Etymologically connected to the Latin word virgo 'virgin' (NPI 2005 s.v. Virginia).

8 The most famous was Julia the elder, daughter of Augustus Caesar, the first Roman Emperor, and his second wife, Scribonia (NPI 2005 s.v. Giulia). In this case, it is also the name of the gens Julia, the Roman noble lineage related to Julius Caesar.

9 The most important was Livia Drusilla, wife of the Roman emperor Augustus throughout his reign, his adviser and mother of the emperor Tiberius (NPI 2005 s.v. Livia).

10 For example, in La Calandria, a comedy of the Italian Renaissance in five acts written by Cardinal Bernardo Dovizi, there was a lady named Fulvia as protagonist (NPI 2005 s.v. Fulvia).

11 Name of characters in many plays. The masculine version of the name, Ortensio, was also the name of many writers of drama of the age, such as the playwright Ortensio Scammacca (1562-1648) and the satirist Ortensio Landi (1531-1598) (NPI 2005 s.v. Ortensio).

12 Delia was the name of the beloved woman of the Roman poet Albius Tibullus in the first book of the Elegies. The name was revived in the Renaissance by authors such as the Italian poet Luigi Tansillo (1510-1568) and the French Maurice Scève (1501-1564), author of Délie obiect de plus haulte vertù.

13 In Roman mythology, Lavinea was the daughter of Latinus and Amata, and the last wife of Aeneas. The tradition of the name was revived in the Renaissance. Lavinia is the name of the figure in love in the Commedia dell'arte, and the name was also chosen from Ariosto for the protagonist in his comedy The Necromancer (1551), which was very popular among contemporaries (NPI 2005 s.v. Lavinia).

14 From the Roman last name Ruffinus, etymologically connected to the Latin word rufus 'red' (NPI 2005 s.v. Ruffino).

15 Altered version of Flora, etymologically connected to the Latin word flos 'flower' (NPI 2005 s.v. Flora). 
Victoria $^{16}$, Centuria ${ }^{17}$, Prudentia ${ }^{18}$ and Valenza ${ }^{19}$. Similar remarks have been made in the historical personal names of Florence (Sestito 2014: 210).

The percentage of names with a historical-dynastic connotation is also quite notable. The names Blanca $^{20}$, Bona $^{21}$ and Violans ${ }^{22}$ are tightly connected to the Savoy house. Isabel is supported by important figures of the House of Savoy as well, but also connected to the French and Spanish crowns. Leonora is supported by important figures of the Italian aristocracy, such as Eleonora d'Este (1537-1581), but also by timeless icons as Eleanor of Aquitaine (11221204), queen consort of France and England and duchess of Aquitaine (NPI 2005 s.v. Eleonora).

There is also a representation of literary names, mostly given by the dominant classes, who were sensitive to literary fashions. In fact, some names of recent literary introduction appear. The epic poem Orlando Furioso by Ludovico Ariosto has inspired the names Angelica and Dorelix (both are princesses in the work). Bernardo Tasso's Amadigi has inspired the use Uriana and the ever-popular names inspired by the works of Dante (Beatrix, the beloved woman in The Divine Comedy and in The vita nuova) and Petrarch (Laura, the beloved woman in the Canzoniere). The medieval legend of King Arthur has been revived in the name Genevra, an Italian version of Arthur's wife's name Gwyniver.

Table 2 shows the masculine names chosen by aristocratic families in 1567-1581 in order of frequency. Altogether, 67 nominal types have been given to 152 individuals.

16 From the Latin word victoria 'victory' (NPI 2005 s.v. Victoria).

17 The name is probably based on centurio, -onis, which originally use to mean 'centurion', but later moved on to designate city security officials (NPI 2005 s.v. Centurio).

18 From the homonymous abstract Latin noun that means 'caution' and refers to one of the four cardinal virtues (NPI 2005 s.v. Prudenza).

19 The name is the abstract female form from Latin valens, -ntis 'that is worth', with nominal suffix -ius.

20 There are many duchesses in the House of Savoy called Blanca, among them Bianca del Monferrato (1472-1519), the wife of Carlo I of Savoy (NPI 2005 s.v. Bianca).

21 Among the many examples of duchesses with this name, especially worth mentioning is Bona of Savoy (1449-1503), daughter of Louis of Savoy, second spouse of Galeazzo Maria Sforza, the Duke of Milan (NPI 2005 s.v. Bona).

22 Among the greats characters of the House of Savoy bearing this name there is Violante del Monferrato (14th century) (NPI 2005 s.v. Violante). 
Table 2: Masculine names chosen by aristocratic families from 1567 to 1581

\begin{tabular}{|c|l|c|c|}
\hline Rank & Name & Units & \% of 154 \\
\hline 1 & Franciscus & 15 & 9.9 \\
\hline 2 & Cesar/Julius Cesar & 9 & 5.9 \\
\hline 3 & Johannes Baptista / Baptista & 7 & 4.6 \\
\hline 4 & Johannes Jacobus, Scipio & 6 & 3.9 \\
\hline 6 & Gabriel, Georgius, Hieronimus & 5 & 3.3 \\
\hline 9 & Ascanius, Carolus & 4 & 2.6 \\
\hline 11 & $\begin{array}{l}\text { Alexander, Amedeus, Aurelius, Johannes, Johannes } \\
\text { Antonius, Ludovicus, Octavius }\end{array}$ & 3 & 2.0 \\
\hline 34 & $\begin{array}{l}\text { Adrianus, Antonius, Bartholomeus, Bernardinus, } \\
\text { Hannibal, Johannes Franciscus, Julius, Laurentius, } \\
\text { Melchior, Octavianus, Paulus, Petrus, Samuel, } \\
\text { Sebastianus, Vincentius }\end{array}$ & 2 & 1.3 \\
& $\begin{array}{l}\text { Andreas, Balthasar, Bertonus, Crispinus, Dominicus, } \\
\text { Emanuel, Ferdinandus, Flamineus, Jacobus Franciscus, } \\
\text { Jacobus Reghinus, Johannes Dominicus, Johannes Maria, } \\
\text { Johannes Petrus Laurentius, Johannes Stephanus, Joseph, } \\
\text { Lelio, Lucas, Lucius Marius, Marcus Antonius, Marcus } \\
\text { Aurelius, Martinus, Matheus, Nicolaus, Percivalis, Petrus } \\
\text { Antonius, Petrus Franciscus, Petrus Hieronimus Alfinus, } \\
\text { Philibertus, Philippus, Pompeus, Prosper, Stephanus, } \\
\text { Thimoteus, Thomas, Ursinus }\end{array}$ & 1 & 0.7 \\
\hline
\end{tabular}

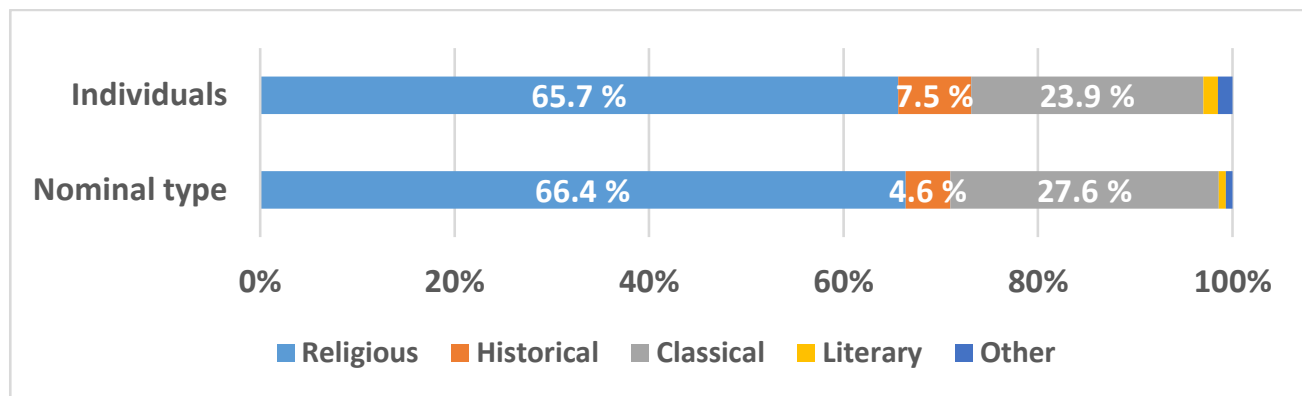

Figure 7: Individual and nominal types of aristocrat male names in 1567-1581 sorted by category

Among the aristocrat male names, the percentage of religious names is higher than among female names: two out of three names fit in this category. Most of them are saints' names: Franciscus, Johannes Jacobus, Georgius, Hieronimus, Carolus, Johannes Baptista/Baptista, Johannes, Johannes Antonius, Ludovicus, Antonius, Bartholomeus, Bernardinus, Johannes Franciscus, Laurentius, Paulus, Petrus, Samuel, Sebastianus, Vincentius, Andreas, Crispinus, Dominicus, Jacobus Franciscus, Jacobus Reghinus, Johannes Dominicus, Johannes Maria, Johannes Petrus Laurentius, Johannes Stephanus, Joseph, Luca, Martinus, Matheus, Nicolaus, Petrus Antonius, Petrus Franciscus, Petrus Hieronimus Alfinus, Philippus, Stephanus, Timotheus and Thomas. Gabriel, Melchior and Balthasar are devotional names. 
When looking at the saints' names, the first thing to notice are the double and triple sequences, consecutive saints' names. They were very frequent and successful in Piedmont, and therefore Papa (2005: 19) has found that they should be considered as autonomous. Georgius, on the other hand, is a successful name because it is the patron saint of the town of Chieri. Some saints' names, for example Carolus $^{23}$, are historical-dynastical names as well. There are also names that designate powerful figures from the city's elite, e.g. Bernardinus ${ }^{24}$ and Bartolomeus $^{25}$. Ludovicus is a name that encompasses the historical-dynastic prestige of many kings of the past ${ }^{26}$ and of many illustrious characters of the time in Chieri ${ }^{27}$. As for the devotional names, the most frequent is the name of the archangel, Gabriel. In addition, the names of two of the three wise men, Melchior and Balthasar, became very common and successful after the Council of Trent.

As it happens for the female fashion, also for the male universe the choice of a name of classical tradition (mostly Greek and Latin), which recalls the revival of the ancient culture of the period, was usual. Those names are Cesar/Julius Cesar, Scipio, Ascanius, Alexander, Aurelius, Octavius, Adrianus, Hannibal, Julius, Octavianus, Flamineus, Lucius Marius, Marcus Antonius, Marcus Aurelius, Pompeius and Ursinus. Those are mainly names of the great leaders of the Classical Age: Cesar/Julius Cesar stands out above all, followed by Scipio ${ }^{28}$. There are also references to the mythical founder of the Latin lineage Ascanius, to the Carthaginian general Hannibal, followed by the Macedonian king Alexander the Great, and the Roman emperors Octavianus and Marcus Aurelius. Among the leaders of the Republican Age are Marcus Antonius, Pompeus, whereas Hercules comes from Greek mythology. There are also more generic references to the noble

23 There are many historical figures connected to the aristocracy of the time: Carlo II, Duke of Savoy (1486-1553); Charles V of Habsburg emperor (1500-1558); Carlo Emanuele I, duke of Savoy (1562-1630).

24 In the 16th century Chieri, Bernardino is the name of many eminent figures. Bernardino Broglia was a noble member of one of the oldest and most influential Chierese bloodlines, famous and active especially in the 1560's and 1570's for having firmly opposed the unfair taxation of Emanuele Filiberto (Allegra 1987: 176). There were also Bernardino Avarengo, son of the most important banker of Chieri in the 1560's (Mignozzetti 2012: 34), and Bernardino Pansa, the mayor in 1570 (Valimberti 1928: LII).

25 At the beginning of the century, there two mayors called Bartolomeo, Bartolomeo Romella dei Radicati (1500) and Bartolomeo dei Signori di Cocconato (1513). Also worth noticing is the banker-merchant Bartolomeo Pasio di Pecetto, active around the 1560's (Valimberti 1928: L).

26 For example, Louis/Ludovico IX of France (1214-1270) and Louis/Ludovico, Duke of Savoy (1413-1465).

27 In the 16th century Chieri, the name Ludovico recalls the figure of Ludovico Broglia. He was admiral and grand prior of Venice in the order of Malta, bailiff of Santo Stefano in Puglia, fought against the Turks in 1534 and worked as an ambassador for the Pope. His adventurous life is narrated on a plaque located in the Church of San Domenico. Ludovico Roglia, entrepreneur and consul in 1577, should also be noticed (Allegra 1987: 195).

28 As for Scipio, the references to the Roman leader are almost all from aristocratic part, they regard 6 of 7 total occurrences. 
Latin gentes in the names Aurelius, Julius, Flamineus and Lelio.

Compared to female names, the category of historical characters names is more represented and more varied, where the historical-dynastic names related to the Savoy House stand out. The most frequent is Amedeus ${ }^{29}$, followed by Emanuel and Philibertus ${ }^{30}$; the reference to the great European dynasties emerges in Ferdinandus ${ }^{31}$; on the other hand, a medieval name that is very locally connotated is Bertonus (in the overall corpus there are also Bertinus, Bertolinus and the feminine Bertolina).

The influence of literature on male names, however, is indeed sporadic. Only the name Percivalis reveals the inspiration from the poems of the Arthurian cycle. There is also one name that cannot be ascribed to any of these categories. An auspicious name Prosper was given to a child registered in a non-standard manner (Table 3). The parents are referred to as magnifici domini (gen.) and his lover (eius amasie). Mother's name is cancelled in the act probably to protect the reputation of the man, an eminent person. It is also significant that the recording is written in a smaller writing in the lower margin of the page, and that the godfather is a member of the eminent Broglia family ${ }^{32}$.

Table 3: A baptismal act from 1580

\begin{tabular}{|c|c|c|c|c|}
\hline name & date & father & mother & godfather \\
\hline prosper & $18 / 10 / 1580$ & $\begin{array}{c}\text { mag(nifi)ci d(omi)ni } \\
\text { georgi de quarinis }\end{array}$ & $\begin{array}{c}\text { et eius } \\
\text { amasie }\end{array}$ & $\begin{array}{c}\text { mag(nifi)cus d(omi)n(u)s } \\
\text { cathelanus broglia }\end{array}$ \\
\hline
\end{tabular}

Chieri élite's passion for the names from classical world sometimes lasted over generations. Some examples of this phenomenon can be observed in Table 4. For example, the noble Bernardino Broglia has chosen the names Lelio and Flaminio for his twin sons. This shows his admiration for the Roman history in its Republican phase, as the names evidently refer to Gaio Flaminio and Gaio Lelio, protagonists of the Roman political and military scene between 265 and $160 \mathrm{BC}$. The choice of the eminent Paolo Balsamo for his two sons falls, instead, on the names of the two commanders Alexander and Marcusantonius. Gaspare Broglia has chosen classical names Valenza, Delia and Octavius for three of his four children in three cases out of four (the eldest is called Caterina).

29 It was the name of many members of the House of Savoy, among them Amedeo VI of Savoy (1343-1383) and Amedeo VIII (1383-1451) count of Savoy and Bonne of Berry (NPI 2005 s.v. Amedeo).

30 The figure of Emanuele Filiberto of Savoy (1538-1580) represented certainly an important reference for both names.

31 Among the many European sovereigns with this name, we can mention Ferdinand II, King of Aragon (1452-1516), and Ferdinand I of the Hapsburgs (1503-1564), Holy Roman Emperor from 1556.

32 The Broglia family was one of the oldest in Chieri, owner of several chapels of the "Collegiata" in different times of its history, also active in the merchant and banking business (Mignozzetti 2012: 159). 
Table 4: Baptismal acts of from 1567 to 1579

\begin{tabular}{|r|l|l|l|}
\hline name & \multicolumn{1}{|c|}{ date } & \multicolumn{1}{c|}{ father } & \multicolumn{1}{c|}{ mother } \\
\hline scipio & $/ 10 / 1567$ & domini claudi cesaris & \\
\hline alexander & $29 / 04 / 1568$ & $\mathrm{~d}($ omi)ni pauli balsami & \\
\hline marchusantonius & $28 / 05 / 1569$ & $\mathrm{~d}($ omi)ni pauli balsami & \\
\hline lelio & $04 / 09 / 1576$ & $\mathrm{~s}$ (ign)or bernardino brolia & \\
\hline flaminio & $04 / 09 / 1576$ & $\mathrm{~s}$ (ign)or bernardino brolia & \\
\hline valenza & $05 / 09 / 1577$ & $\mathrm{~s}$ (ign)or gaspardo brolia & \\
\hline delia & $05 / 09 / 1577$ & $\mathrm{~s}($ ign)or gaspardo brolia & \\
\hline lucretia & $03 / 11 / 1578$ & $\mathrm{~d}($ omi)ni cesari & maria jug(aliu)m de solaris \\
\hline fulvia & $28 / 01 / 1579$ & mag(nifi)ci d(omi)ni gasparis & marie jug(aliu)m de brolia \\
\hline & $17 / 05 / 1579$ & $\begin{array}{l}\text { mag(nifi)ci d(omi)ni } \\
\text { glaudi cesaris }\end{array}$ & $\begin{array}{l}\text { leonore jug(aliu)m de } \\
\text { dodolis }\end{array}$ \\
\hline
\end{tabular}

In some cases, the love for the classical world is a naming device that serves to connect generations. This is the case of the daughter of the noble Claudio Cesare Dodoli, who named one daughter Fulvia and one son Scipio, while Mr. Cesare Solari named his daughter Lucretia. Here is also visible the influence of the most talked-about couple of the 16th century, Lucrezia and Cesare Borgia.

\section{Baptismal names.}

\section{A comparison between élite's choices and the whole system}

Finally, we can compare upper classes' name choices to general name statistics of the time. Table 5 presents 20 most popular female and male names during the research period, including all classes. When looking at the list of most popular female names, we can see that they are almost exclusively religious names, far more often than in the list of most popular aristocratic names. Classical, historical and literary names, for example Lucretia, Leonora and Beatrix, are at lower ranks.

The chart in Figure 8 shows how the female names are distributed in the categories of religious, historical, classical, literary and other names. The chart emphasizes the difference between name choices of aristocrats and other people. Among the aristocrats, $60 \%$ have chosen a religious name, whereas among the others the percentage is $85 \%$. Classical names, which made $28 \%$ of aristocratic name choices, are only $7 \%$ among the ordinary people. Literary names are also given more often by aristocrats $(6 \%)$ than others $(2 \%)$.

In the masculine stock of names (Table 5), the power of religious names is even more persistent. For example Cesar, the second most common male name in the stock related to upper classes, is at rank 20 here. The distributions of male names among the aristocrats and the others (Figure 8) are quite similar to the female names, even though the percentages of religious names are even 
slightly higher. Religious names make $66 \%$ of aristocrats' and $87 \%$ of others' name choices, whereas classical names represent $28 \%$ of aristocrats but only $8 \%$ of common people's name choices.

Table 5: Most common feminine and masculine names in the whole name system between 1567 and 1581

\begin{tabular}{|c|c|c|c|c|c|}
\hline Name & Units & $\%$ & Name & Units & $\%$ \\
\hline Margarita & 179 & 12.0 & Johannes & 111 & 7.3 \\
\hline Catharina & 170 & 11.4 & Franciscus & 93 & 6.1 \\
\hline Anna & 161 & 10.8 & Antonius & 79 & 5.2 \\
\hline Maria & 156 & 10.5 & Johannes Antonius & 75 & 4.9 \\
\hline Johanna & 117 & 7.9 & Bernardinus & 52 & 3.4 \\
\hline Antonia & 48 & 3.2 & Jacobus / Jacomus & $52(51+1)$ & 3.4 \\
\hline Francisca & 42 & 2.8 & Johannes Jacobus & 47 & 3.1 \\
\hline Lucia & 36 & 2.4 & Bartholomeus & 46 & 3.0 \\
\hline Jacobina / Jacoma & $35(32+3)$ & 2.4 & Michael & 45 & 2.9 \\
\hline Bartholomea & 30 & 2.0 & Georgius & 41 & 2.7 \\
\hline Ludovica & 28 & 1.9 & Sebastianus & 38 & 2.5 \\
\hline Lucretia & 27 & 1.8 & Gaspar & 36 & 2.4 \\
\hline Beatrixina & 26 & 1.7 & $\begin{array}{c}\text { Johannes } \\
\text { Baptista / Baptista }\end{array}$ & $\begin{array}{c}36 \\
(27+9) \\
\end{array}$ & 2.4 \\
\hline Julia & 26 & 1.7 & Dominicus & 33 & 2.2 \\
\hline Isabel & 23 & 1.5 & Petrus & 31 & 2.0 \\
\hline Laura & 21 & 1.4 & Johannes Franciscus & 29 & 1.9 \\
\hline Angela & 20 & 1.3 & Matheus & 29 & 1.9 \\
\hline Paula & 19 & 1.3 & Gabriel & 28 & 1.8 \\
\hline Agnes & 18 & 1.2 & Thomas & 25 & 1.6 \\
\hline Bernardina & 15 & 1.0 & Cesar / Julius Cesar & $24(13+11)$ & 1.6 \\
\hline
\end{tabular}

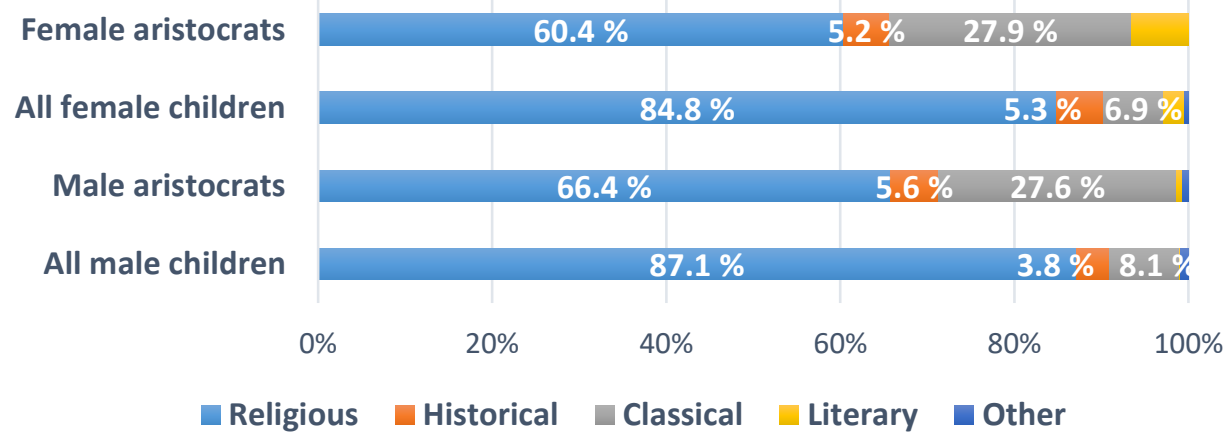

Figure 8: The distribution of aristocrat names and all given names in 1567-1581 


\section{Conclusions}

To sum up, the upper classes of Chieri were the social groups that understood better the wide range of onomastic fashion in the age in which they lived. They chose religious names, supported by the Council of Trent, but they were also aware of the renewal of the classical world. They paid homage to prominent historical characters, especially of the Savoy lineage. Finally, they demonstrated love for contemporary literature as well for the fourteenth century classics, but only in female names. When compared to the ordinary people at the time, aristocrats were distinctively eager to give other than religious names, especially names from the classical culture.

Future projects about this topic are a diachronic evolution of the stock of names favoured by the aristocrats and a deepening of the study on families.

\section{References}

Alessio, Felice. 1905. Primordi del Cristianesimo in Piemonte [Beginnings of Christianity in Piedmont]. Pinerolo: Tipografia Chiantore-Mascarelli.

Allegra, Luciano. 1987. La città verticale. Usurai, mercanti e tessitori nella Chieri del Cinquecento [The vertical city. Usurers, merchants and weavers in the city of Chieri in the sixteenth century]. Torino: Franco Angeli.

Bloch, Marc. 1964. Les caractères originaux de l'histoire rurale française [The original characters of French rural history], 2 vols. Paris: Armand Colin.

Bassignana, Enrico. 1986. Duomo di Chieri: 15 secoli di storia e fede [The Chieri Cathedral: 15 centuries of history and faith]. Pinerolo: Arti Grafiche Alzani.

Catechismus ex decreto Concilii Tridentini. 1567. Ad parochos, Pii Quinti Pont. Romae: in aedibus Populi Romani, apud Paulum Manutium.

Cibrario, Luigi. 1827. Delle storie di Chieri libri quattro con documenti [Of the stories of Chieri, four books with documents]. Torino: Alliana.

DTI = Gasca Queirazza, Giuliano \& Marcato, Carla \& Pellegrini, Giovan Battista \& Petracco Sicardi, Giulia \& Rossebastiano, Alda. 1997. Dizionario di toponomastica. Storia e significato dei nomi geografici italiani [Dictionary of toponymy. History and meaning of Italian geographic names]. Torino: UTET.

Gabotto, Ferdinando. 1913-1924. Appendice al Libro Rosso del Comune in Statuti civili del Comune di Chieri [Appendix to the Red Book of the Municipality in Civil Statutes of the Municipality of Chieri]. Pinerolo: Tipografia Chiantore-Mascarelli.

Giugni, Ugo. 2004. San Pio V, Il Papa della S. Messa e di Lepanto [The Pope of the Holy Mass and of Lepanto]. Centro Librario Sodalitium: Verrua Savoia. 
Mignozzetti, Antonio. 2012. Il Duomo di Chieri. Note storico-religiose [The Cathedral of Chieri. Historical-religious notes]. Torino: Edizioni Mille Eurotarget.

NPI = Rossebastiano, Alda \& Papa, Elena. 2005. Nomi di persona in Italia . Dizionario storico ed etimologico [Personal names in Italy. Historical and etymological dictionary]. Torino: UTET.

Papa, Elena. 2005. Il primo nome tra identità personale e sociale: il quadro onomastico eporediese nel $X V$ e XVI secolo [The individual name between personal and social identity: The Eporedian onomastic picture in the 15th and 16th centuries]. Torino: Libreria Stampatori.

Paschalis, Michael. 1997. Virgil's Aeneid: Semantic relations and proper names. Oxford: Clarendon Press.

Rossi, Elisabetta. 2019. Antroponimia femminile nel Piemonte del XVI secolo: variabilità linguistica e stratigrafia sociale [Female anthroponymy in Piedmont of the 16th century: Linguistic variability and social stratigraphy]. Torino. (Unpublished doctoral thesis.)

Sestito, Francesco. 2014. Inomi di battesimo a Firenze (1450-1900). Dai registri di Santa Maria del Fiore un contributo allo studio dell'antroponimia storica italiana [Individual names in Florence (1450-1900). From the registers of Santa Maria del Fiore a contribution to the study of Italian historical anthroponymy]. Roma: Società Editrice Romana.

Valimberti, Bartolomeo. 1928. Spunti storico-religiosi sopra la città di Chieri [Historical-religious background on the city of Chieri], vol. I: Il Duomo. Chieri: Tipografia Ghirardi.

Wilson, Stephen. 1998. The means of naming. A social and cultural history of personal naming in western Europe. Padstow: UCL Press. 